\title{
Post-infection irritable bowel syndrome in the tropical and subtropical regions: Vibrio cholerae is a new cause of this well-known condition
}

\author{
Uday C. Ghoshal $^{1}$ - M. Masudur Rahman ${ }^{2}$ \\ Published online: 9 May 2019 \\ (C) Indian Society of Gastroenterology 2019
}

Following acute infective gastroenteritis, $4 \%$ to $37 \%$ of patients develop new-onset persistent bowel symptoms fulfilling the Rome criteria for irritable bowel syndrome (IBS), an entity recently named as post-infection IBS (PI-IBS) [1]. The acute episode of gastroenteritis should fulfill at least two of the four criteria, namely diarrhea, fever, vomiting, and positive stool culture. PI-IBS develops mostly following acute infectious diarrhea due to multiple etiological agents, more so due to invasive pathogens (Table 1). However, a few studies did report the occurrence of PI-IBS following infection due to less invasive pathogens causing diarrhea such as viruses [19, 22]. Hence, the conventional belief that the PI-IBS occurs predominantly following acute gastroenteritis due to invasive pathogen is no more tenable. Moreover, two recent studies, one from Bangladesh and another one published in this issue of the Journal from India, showed the occurrence of PI-IBS following infection with Vibrio cholerae (V. cholerae), conventionally known as a noninvasive pathogen, challenging this belief further [27, 28].

In a recent study from Bangladesh by Rahman and Ghoshal, of 345 patients with acute gastroenteritis admitted to the International Centre for Diarrheal Disease Research, Dhaka, 16.5\% developed PI-IBS as compared with $2.6 \%$ controls during 12-month follow up; similarly, $7.4 \%$ of them developed functional dyspepsia (FD) in contrast to $0.6 \%$ controls during the same follow up duration. Of 245 patients undergoing etiological workup for gastroenteritis, $39 \%$ had cholera. Frequency of PI-IBS was

Uday C. Ghoshal

udayghoshal@gmail.com

1 Department of Gastroenterology, Sanjay Gandhi Postgraduate Institute of Medical Sciences, Lucknow 226 014, India

2 Department of Gastroenterology, Sheikh Russel Gastroliver Institute and Hospital, Dhaka, Bangladesh similar among patients with cholera and those with other infection causing acute gastroenteritis. In the Indian study published in this issue of the Journal, of 136 patients with acute gastroenteritis admitted to SCB Medical College, Cuttack, India, 25.7\% developed PI-IBS at 6 months. Of 11 patients who had cholera, 4 developed PI-IBS, further proving the role of V. cholerae in the development of this condition.

Considering the high global burden of cholera, the clinical, epidemiological, societal, and economic implications of the finding that cholera can lead to PI-IBS cannot be overestimated. There are 1.3 billion people at risk of cholera in the 69 cholera-endemic countries [29, 30]. It is estimated that each year, there are 1.3 to 4.0 million cases of cholera [29]. The actual number may be higher due to under-reporting $[29,31]$. Of 69 countries in the world considered as choleraendemic, India, Nigeria, China, Ethiopia, and Bangladesh are the countries in which the largest number of people are at risk for developing cholera. The finding that PI-IBS can develop following cholera has important economic implication for these nations not only due to the potential risk of mortality due to cholera, its morbidity, health care burden, and loss of work productivity of the inhabitants but also because of fear among travelers from the developed countries of developing chronic gastrointestinal (GI) diseases such as PI-IBS and PI$\mathrm{FD}$, potentially resulting in national economic loss. More studies are needed on these issues.

\section{Mechanisms of cholera-induced PI-IBS}

The rapidly developing non-inflammatory diarrhea, which is typical characteristics of cholera, is widely known to be caused by cholera toxin (CT). However, V. cholerae strain devoid of genes for CT can cause mild to moderate diarrhea suggesting additional mechanisms for diarrhea in cholera [32-34]. Apart from CT, there are three more toxins (zonula 
Table 1 Incidence, etiology of acute gastroenteritis, and risk factors for post-infection irritable bowel syndrome in cases and controls

\begin{tabular}{|c|c|c|c|c|c|}
\hline Study details & Country & Cause of gastroenteritis & IBS in cases $(\%)$ & IBS in controls & $\begin{array}{l}\text { Risk factors for } \\
\text { post-infection IBS }\end{array}$ \\
\hline McKendrick and Read (1994) [2] & UK & Salmonella & $12 / 38(31.6)$ & No control & $\begin{array}{l}\text { Severity of acute illness, } \\
\text { vomiting, and weight } \\
\text { loss }\end{array}$ \\
\hline Gwee et al. (1996) [3] & UK & $\begin{array}{l}\text { Shigella, Campylobacter, } \\
\text { Salmonella }\end{array}$ & $20 / 75(26.6)$ & No control & $\begin{array}{l}\text { Anxiety, depression, } \\
\text { somatisation, and } \\
\text { neurotic trait }\end{array}$ \\
\hline Neal et al. (1997) [4] & UK & Bacteria & $23 / 347(6.6)$ & No control & $\begin{array}{l}\text { Longer duration of } \\
\text { diarrhea, younger } \\
\text { age, and female sex }\end{array}$ \\
\hline Gwee et al. (1999) [5] & UK & - & 19/109 (17.4) & $\begin{array}{l}\text { Psychological and } \\
\text { rectal biopsy: } \\
21 \text { HS }\end{array}$ & $\begin{array}{l}\text { Psychological factors } \\
\text { and persistent rectal } \\
\text { inflammation }\end{array}$ \\
\hline Rodriguez and Ruigomez (1999) [6] & UK & Bacteria & $14 / 318(4.4)$ & $2027 / 584308(0.3 \%)$ & Not evaluated \\
\hline Mearin et al. (2005) [7] & Spain & Salmonella & $13.2 \%$ & $1.5 \%$ & No risk factor identified \\
\hline Ilnyckyj et al. (2003) [8] & Canada & Traveler's diarrhea & $2 / 48(4.2)$ & $1 / 61(1.6 \%)$ & Not evaluated \\
\hline Dunlop et al. (2003) [9] & UK & Campylobacter & $103 / 747(13.8)$ & No control & $\begin{array}{l}\text { Increased enterochromaffin } \\
\text { cells in lamina propria } \\
\text { and depression }\end{array}$ \\
\hline Parry et al. (2003) [10] & UK & Campylobacter, Salmonella & $18 / 108(16.7)$ & $4 / 219(1.9 \%)$ & Not evaluated \\
\hline Wang et al. (2004) [11] & China & Shigella & $24 / 295(8.1)$ & $2 / 243(0.8 \%)$ & $\begin{array}{l}\text { Longer diarrhea, IL-1 } \beta \\
\text { mRNA expression, } \\
\text { and mast cell in ileum } \\
\text { and rectosigmoid }\end{array}$ \\
\hline Okhuysen et al. (2004) [12] & USA & Traveler's diarrhea & $60(6)$ & No control & $\begin{array}{l}\text { More diarrhea, medical } \\
\text { consultation, and stool } \\
\text { negative for the pathogen }\end{array}$ \\
\hline Ji et al. (2005) [13] & Korea & Shigellosis & 15/101 (14.8) & $6 / 102(5.8 \%)$ & Diarrhea duration \\
\hline Parry et al. (2005) [14] & UK & Bacteria & 16/107 (15) & No control & Smoking \\
\hline Kim et al. (2006) [15] & Korea & Shigella & 13/95 (13.6) & $4 / 105(3.8 \%)$ & $\begin{array}{l}\text { Pre-existing FBD other } \\
\text { than IBS }\end{array}$ \\
\hline Marshall et al. (2006) [16] & Canada & E. coli, Campylobacter & $417 / 1368(30.5)$ & $71 / 701(10.2 \%)$ & $\begin{array}{l}\text { Young age, female, bloody } \\
\text { stools, weight loss, and } \\
\text { long diarrhea }\end{array}$ \\
\hline Borgaonkar et al. (2006) [17] & Canada & Bacteria & 7/191 (3.7) & No control & Fever during gastroenteritis \\
\hline Stermer et al. (2006) [18] & Israel & Traveler's diarrhea & 16/118 (13.6) & $7 / 287(2.4 \%)$ & $\begin{array}{l}\text { Female gender, abdominal } \\
\text { pain, prolonged diarrhea, and } \\
\text { antibiotic use }\end{array}$ \\
\hline Marshall et al. (2007) [19] & Canada & Viral diarrhea & 21/89 (23.6) & $1 / 29(3.4 \%)$ & Vomiting during gastroenteritis \\
\hline Spence et al. (2007) [20] & New Zealand & Campylobacter & $86 / 581(14.8)$ & No control & $\begin{array}{l}\text { Psychological co-morbidity } \\
\text { and lack or rest during } \\
\text { gastroenteritis }\end{array}$ \\
\hline Hanevik et al. (2009) [21] & Norway & Giardia & $66 / 82(80.5)$ & No control & Not evaluated \\
\hline Zanini et al. (2012) [22] & Italy & Norovirus & $40 / 186(21.5)$ & $3 / 198(1.5 \%)$ & Not evaluated \\
\hline Cremon et al. (2014) [23] & Italy & $\begin{array}{l}\text { Salmonella enterica subsp. } \\
\quad \text { enterica serovar Typhi }\end{array}$ & $75 / 204(36.8)$ & $44 / 189(23.3 \%)$ & $\begin{array}{l}\text { Anxiety and functional } \\
\text { dyspepsia }\end{array}$ \\
\hline Persson et al. (2015) [24] & Norway & Giardia & 224/724 (32) & 96/847 (11.4\%) & Not evaluated \\
\hline Wadhwa et al. (2016) [25] & USA & Clostridium difficile & $52 / 205(25)$ & No control & $\begin{array}{l}\text { Longer infection duration, } \\
\text { current anxiety, and } \\
\text { higher BMI }\end{array}$ \\
\hline Andresen et al. (2016) [26] & Germany & $\begin{array}{l}\text { Shiga-like toxin-producing } \\
\text { E. coli }\end{array}$ & $98 / 389(25.3)$ & No control & $\begin{array}{l}\text { Higher somatization and } \\
\text { anxiety scores }\end{array}$ \\
\hline Rahman and Ghoshal (2018) [27] & Bangladesh & $\begin{array}{l}\text { E. coli, Campylobacter } \\
\text { V. Cholera, Salmonella, } \\
\text { Shigella, Aeromonas }\end{array}$ & $57 / 345(16.5)$ & $9 / 345(2.6 \%)$ & $\begin{array}{l}\text { Dyspeptic symptoms, } \\
\text { continuing bowel } \\
\text { dysfunction, and } \\
\text { weight loss }\end{array}$ \\
\hline Current study (2019) [28] & India & $\begin{array}{l}\text { E. coli, Campylobacter } \\
\text { V. Cholerae, Salmonella, } \\
\text { Shigella, Y. enterocolitica }\end{array}$ & $35 / 136(25.7)$ & No control & $\begin{array}{l}\text { Younger age, prolonged } \\
\text { duration of diarrhea, } \\
\text { and abdominal cramps }\end{array}$ \\
\hline
\end{tabular}

$I B S$ irritable bowel syndrome, $H S$ healthy subject, $F B D$ functional bowel disease, $B M I$ body mass index

occludens toxin [Zot], accessory cholera enterotoxin [Ace], hemolysin/cytolysin toxin), which are found almost in all strains of V. cholerae, and several more toxins (Shiga-like toxin, ST, new cholera toxin, sodium channel inhibitor, and thermostable direct hemolysin) are found in a small proportion of patients $[32,34]$. The classical mechanisms of action of CT 
are cAMP-dependent ion transport activation leading to increased $\mathrm{Cl}^{-}$secretion in crypt cells and reduced $\mathrm{NaCl}$-coupled absorption in the villous cells. There are alternate or additional mechanisms by which CT stimulates intestinal secretions. These are (a) prostaglandin secretions, (b) activation of the enteric nervous system (ENS), (c) alteration in epithelial barrier function, (d) intestinal inflammatory response, and (e) immunomodulation. A number of studies suggest that prostaglandins (PGE1 and PGE2) and platelet-activating factor (PAF) are involved in the pathogenesis of intestinal secretion caused by CT [35-39]. CT stimulates the epithelial cell phospholipase to produce prostaglandins (PGs). PG production at the submucosal compartment has also been implicated in the pathogenesis of diarrhea in cholera [34]. CT causes activation of ENS. There are number of evidences that suggest the role of CT in ENS activation: (i) a variety of ganglionic or neurotransmitter blockers inhibit the CT-induced secretion [40-42]. 5Hydroxytryptamine (5-HT) receptor antagonists markedly diminish the CT-induced secretion [43]. Vasoactive intestinal peptide (VIP) release from intestine in patients with cholera can be blocked by tetradotoxin [44]. It is estimated that $60 \%$ of the effect of CT on intestinal fluid secretion may result from activation of ENS [41]. CT stimulates ENS by stimulating the 5-HT release by Enterochromaffin (EC) cells and/or by stimulating the smooth muscle cell activity of the small intestine. 5-HT causes intestinal secretions in several ways: (i) directly stimulates ENS leading to VIP secretion, and (ii) causes PG release that either stimulates transport function directly or activates the ENS [32]. CT has immunomodulatory effects. It is a potent oral immunogen having a variety of effects on the cells of the immune system. It stimulates interleukin (IL)-1 production and enhances antigen presentation by macrophages [45]. It promotes B cell isotype differentiation [46] and inhibits Th1 cells [47]. CT can alter the intestinal epithelial barrier function [32]. Altered intestinal epithelial barrier function may also result from zot toxin [48]. CT induces a modest inflammatory response. Duodenal biopsy of cholera patients demonstrated modest inflammation [49]. It stimulates the production of IL-6, which then activates the generation of PGs and leukotrienes that stimulate intestinal secretion. High levels of lactoferrin have been found in stool samples of healthy volunteers infected with $V$. cholerae from which toxin genes have been deleted or mutated [50]. Many of the above-mentioned mechanisms have been implicated in the pathogenesis of PI-IBS. However, the mechanism of cholera in acute stage has been studied extensively; pathophysiological aspects of its long-term consequences such as the development of PI-IBS need to be studied further.

\section{Micro-organic basis of PI-IBS}

Although studies on PI-IBS provide us probably the best evidence for a micro-organic basis of this hitherto enigmatic disorder, the pathophysiological mechanisms of PI-IBS have not been studied much. Current evidence suggests that PI-IBS is complex and is probably a multifactorial disease involving visceral hypersensitivity, gut dysmotility, microbial dysbiosis, altered intestinal permeability, immune dysregulation, alteration in neuroendocrine pathways, and genetic factors [1, 51, 52].

Gut microbiota dysbiosis is associated with acute gastroenteritis, its recovery, and development of PI-IBS [53, 54]. A few studies suggest that susceptibility to GI infection can be increased due to an imbalanced gut microbiota [54, 55]. This may result from a complex interaction between the microbiota and host immune system, which reduces the response to GI infections [56]. Gut microbiota analysis identified potential etiological factors in acute gastroenteritis [57]. In a prospective study, the abattoir workers developing Campylobacter jejuni infection had increased levels of Bacteroides species prior to infection compared with those who did not develop an infection. The uninfected person had significantly higher levels of uncultured Clostridiales [58]. In short-term, altered gut microbiota was found after acute GI infection [59, 60]. Travelers who develop infectious diarrhea have low levels of Bacteroides [61].

PI-IBS patients have the inability to restore the microbial ecosystem after an attack of acute gastroenteritis [1]. The significant difference in gut microbiota profile of PI-IBS patients compared with healthy control has been found [62, 63]. A recent study demonstrated significant difference in gut microbiota profile between the healthy subjects and the patients with PI-IBS (increase in Bacteroides species and decrease in number of uncultured Clostridiales) [62].

In a recent prospective household survey in Bangladesh, the authors found that abnormal gut microbial communities are host factors for susceptibility to $V$. cholerae infection. Susceptibility to cholera was associated with a decreased level of Bacteroides [64]. A study involving time-series metagenomic analysis of fecal samples collected during the acute diarrhea and recovery phases of cholera in a cohort of Bangladeshi adults found that recovery was characterized by a pattern of accumulation of bacterial taxa that showed similarities to the pattern of assembly/maturation of the gut microbiota in healthy Bangladeshi children [65]. When an artificial community composed of human gut bacterial species that directly correlated with recovery from cholera in adults and were indicative of normal microbiota in healthy Bangladeshi children was introduced into gnotobiotic mice, Ruminococcus obeum ( $R$. obeum) exhibited a consistent increase in its relative abundance upon $V$. cholerae infection of the mice. Follow up analyses, including mono- and co-colonization studies, established that $R$. obeum restricts $V$. cholerae colonization [65]. The study demonstrated that during diarrheal or recovery phase (up to 2 months), increase in the relative abundance of species of the genera Bacteroides, Prevotella, Ruminococcus/ Blautia, and Faecalibacterium strongly correlated with a shift 
in community structure towards a healthy adult configuration [65]. It is well-known that IBS in general and PI-IBS, in particular, are associated with gut microbial dysbiosis, which is also associated with susceptibility and occurrence of cholera suggesting a link between PI-IBS and cholera.

There is a complex interaction between gut microbiota and host gene expression and immune response, which are bidirectional $[1,62,63]$. Current evidence suggests that gut microbial composition affects the susceptibility to GI infection by invasive bacteria such as Campylobacter jejuni [58] as well as by V. cholerae [64]. Dysbiosis has been found after acute gastroenteritis by invasive bacteria as well as by $V$. cholerae at least in short-term [65]. However, a number of studies reported the occurrence of PI-IBS after acute gastroenteritis caused by invasive bacteria. Some of the recent studies demonstrated that PI-IBS occurred after cholera and its frequency was comparable to other invasive bacteria [27, 28]. Although the gut microbiota alteration has been studied in PI-IBS after acute gastroenteritis caused by invasive bacteria $[62,63]$, currently, such alteration is unknown among PI-IBS patients resulting from cholera.

\section{Incidence of PI-IBS and its relationship with the hygiene hypothesis}

The frequency of acute gastroenteritis in the tropics including India and Bangladesh is high [66]. On the other hand, in most of the studies, the prevalence of IBS among the general adult population in India and Bangladesh has been found to be between $4 \%$ and $8 \%$ [67], which is lower compared with the global prevalence of $11.2 \%$ [68]. The reason for the low prevalence of IBS in spite of the high prevalence of acute gastroenteritis in these countries remains enigmatic. The hygiene hypothesis was put forward to explain this enigma, which states immune tolerance develops if an individual is exposed repeatedly to the microorganism in early life. Though subsequent infection in later life induces intestinal immune response quickly and effectively resulting in its clearance, the immune activation is switched off rapidly due to a strong Tregulatory function [69]. However, the two current studies from Bangladesh and India on PI-IBS suggest that the frequency of IBS after acute gastroenteritis was $16.5 \%$ and $26 \%$, respectively $[27,28]$. These frequencies are somewhat comparable or higher than those reported in the other studies from the temperate countries (Table 1). Do these findings from these two countries contradict the hygiene hypothesis? To reconcile these findings in the context of the hygiene hypothesis, it is important to review the risk factors for the development of PI-IBS [70].

\section{Risk factors for PI-IBS}

Several risk factors for the development of PI-IBS following an attack of acute gastroenteritis have been identified (Table 1). These include demographic parameters (e.g. young age, female gender, and smoking), gastroenteritis-related variables (e.g. long duration diarrhea of more than 1 week, abdominal pain, blood in the stool, and antibiotic treatment), and psychological factors (anxiety, depression, somatization, neuroticism, adverse life events in preceding year, hypochondriasis, extroversion, negative illness beliefs, and history of stress and sleep disturbance) [70] (Fig. 1).

A risk score was developed and validated by Thabane et al. [71]. The model used demographic factors, psychological stress, and clinical characteristics of acute gastroenteritis that included gender, diarrheal illness lasting more than 7 days, peak frequency of seven or more loose stools per day, and weight loss of at least $10 \mathrm{lbs}$. This risk score has been validated in the Indian study on PI-IBS published in this issue of the Journal [28]. In the original study, three discrete categories were developed for the level of risks; low (score $<42$ ), intermediate (43-68), and high (>69). In the derivation set, $10 \%$, $35 \%$, and $60 \%$ of subjects developed PI-IBS from the low, intermediate, and high-risk score group, with no differences from the validation cohort [71]. In the Indian study, with a cutoff value of $>50$, the sensitivity and specificity of the risk score were $91.4 \%$ and $84.2 \%$, respectively, to predict PI-IBS development at 6 months. These findings suggest that this risk score, which is easy to use, may be clinically useful to guide the therapy and counseling of patients with acute gastroenteritis.

The above-mentioned risk factors for PI-IBS help to reconcile the apparently comparable or greater frequency of PI-IBS in the tropical rather than the temperate world that seems to challenge the hygiene hypothesis (Table 1). Since all the patients in the Indian and the Bangladeshi studies were admitted to the hospitals, expectedly had severe gastroenteritis, and a large proportion received antibiotics, there is a possibility of over-estimation of the frequency of PI-IBS in these series. More studies, therefore, are needed including consecutive patients with acute gastroenteritis attending outpatient clinics without specific risk factors for PI-IBS to know its true frequency after an attack of acute gastroenteritis in tropical countries.

\section{Tropical sprue vs. PI-IBS}

Tropical sprue (TS) has been reported from southern India almost seven decades ago [72]. It has also been reported from Vietnam, Burma, and eastern India (present-day Bangladesh) $[73,74]$ and recently from the USA [75]. Several studies on malabsorption have demonstrated that TS is still the leading cause of sporadic malabsorption in India [76-78]. Epidemic TS or post-infectious malabsorption (PI-MAS) has 


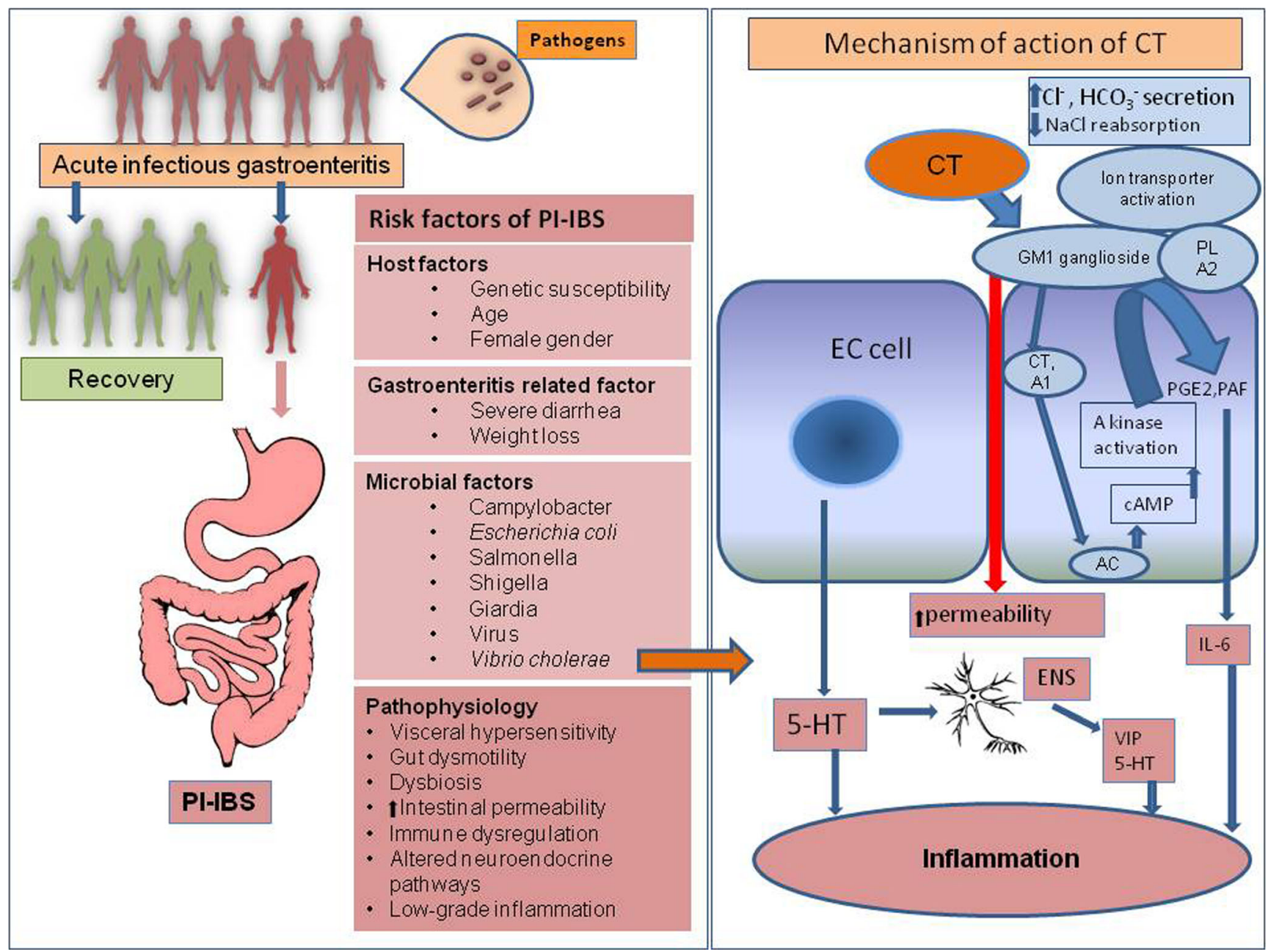

Fig. 1 Risk factors and pathophysiology of post-infection irritable bowel syndrome (PI-IBS) and mechanism of action of cholera toxin. CT cholera toxin, $A C$ adenylate cyclase, $P L-A 2$ phospholipase A2, $P G E 2$ prostaglandin E2, $P A F$ platelet activating factor, 5-HT 5-hydroxytryptamine, ENS enteric nervous system, VIP vasoactive intestinal polypeptide, $E C$ cell enterochromffin cell, $I L-6$ interleukin-6, cAMP cyclic adenosine monophosphate epidemiologic, clinical, and pathophysiological similarities with PI-IBS [51, 73, 74]. Both the disorders occur after an attack of acute gastroenteritis. The predominant clinical features are chronic diarrhea in both the disorders. Abnormal intestinal permeability, small intestinal bacterial overgrowth, abnormal gut motility, and neurohormonal dysfunction have been found both in PI-MAS and PI-IBS [51, 73, 74]. Since PIIBS is a symptom-based diagnosis by current Rome criteria [1], it is possible that some patients with PI-MAS without overt malnutrition are diagnosed as PI-IBS by symptombased criteria. However, none of the previous studies on PIIBS excluded the PI-MAS by tests of mucosal malabsorption except one recent study from Bangladesh. In this study, the authors found that about $9 \%$ of the patients fulfilling the Rome III criteria of PI-IBS had at least two abnormal mucosal absorption tests, (i) D-xylose hydrogen breath test, (ii) fecal fat microscopy using Sudan III stain, and (iii) histopathological examination of duodenal biopsies obtained endoscopically, suggesting these patients had PI-MAS or tropical sprue. In this study, $22 \%$ of the 23 subjects who were investigated for malabsorption had at least one test abnormal [27]. This study suggests that the patients who develop continued bowel symptoms after acute gastroenteritis need to be investigated for mucosal malabsorption even though they might have fulfilled the Rome criteria for IBS; this highlights the importance of further study on this issue on larger number of patients.

\section{Summary and future direction}

Two recent studies from India and Bangladesh, including one published in this issue of the Journal, have demonstrated that infection with $V$. cholerae is a risk factor for the development PI-IBS. The frequency of PI-IBS following acute gastroenteritis in these two countries is comparable or higher than that in the other studies published previously. However, further 
prospective case-control studies are needed to know the risk of PI-IBS in less severe forms of acute gastroenteritis caused by different pathogens including $V$. cholerae in tropical countries. Similarly, further validation of the risk score is needed in less severe forms of acute gastroenteritis. Although a number of mechanistic studies including gut microbiota have been conducted in acute cholera, how this infection leads to long-term consequences including PI-IBS requires further studies. About $9 \%$ of the patients who are diagnosed as PI-IBS actually had PI-MAS in the Bangladeshi study, and this issue has not been investigated in the Indian study. More studies are needed on this issue. Clinical and economic consequences of acute gastroenteritis among travelers from temperate to tropical countries are also important issues that require further study.

\section{Compliance with ethical standards}

Conflict of interest UCG, and MMR declare that they have no conflict of interest.

Disclaimer The authors are solely responsible for the data and the content of the paper. In no way, the Honorary Editor-in-Chief, Editorial Board Members, or the printer/publishers are responsible for the results/ findings and content of this article.

\section{References}

1. Barbara G, Grover M, Bercik P, et al. Rome Foundation working team report on post-infection irritable bowel syndrome. Gastroenterology. 2019;156:46-58. e7.

2. McKendrick MW, Read NW. Irritable bowel syndrome-post salmonella infection. J Inf Secur. 1994;29:1-3.

3. Gwee KA, Graham JC, McKendrick MW, et al. Psychometric scores and persistence of irritable bowel after infectious diarrhoea. Lancet. 1996;347:150-3.

4. Neal KR, Hebden J, Spiller R. Prevalence of gastrointestinal symptoms six months after bacterial gastroenteritis and risk factors for development of the irritable bowel syndrome: postal survey of patients. BMJ. 1997;314:779-82.

5. Gwee KA, Leong YL, Graham C, et al. The role of psychological and biological factors in postinfective gut dysfunction. Gut. 1999;44:400-6.

6. Rodriguez LA, Ruigomez A. Increased risk of irritable bowel syndrome after bacterial gastroenteritis: cohort study. BMJ. 1999;318: 565-6.

7. Mearin F, Perez-Oliveras M, Perello A, et al. Dyspepsia and irritable bowel syndrome after a Salmonella gastroenteritis outbreak: one-year follow-up cohort study. Gastroenterology. 2005;129:98-104.

8. Ilnyckyj A, Balachandra B, Elliott L, Choudhri S, Duerksen DR. Post-traveler's diarrhea irritable bowel syndrome: a prospective study. Am J Gastroenterol. 2003;98:596-9.

9. Dunlop SP, Jenkins D, Neal KR, Spiller RC. Relative importance of enterochromaffin cell hyperplasia, anxiety, and depression in postinfectious IBS. Gastroenterology. 2003;125:1651-9.

10. Parry SD, Stansfield R, Jelley D, et al. Does bacterial gastroenteritis predispose people to functional gastrointestinal disorders? A prospective, community-based, case-control study. Am J Gastroenterol. 2003;98:1970-5.
11. Wang LH, Fang XC, Pan GZ. Bacillary dysentery as a causative factor of irritable bowel syndrome and its pathogenesis. Gut. 2004;53:1096-101.

12. Okhuysen PC, Jiang ZD, Carlin L, Forbes C, DuPont HL. Postdiarrhea chronic intestinal symptoms and irritable bowel syndrome in north American travelers to Mexico. Am J Gastroenterol. 2004;99:1774-8.

13. Ji S, Park H, Lee D, Song YK, Choi JP, Lee SI. Post-infectious irritable bowel syndrome in patients with Shigella infection. J Gastroenterol Hepatol. 2005;20:381-6.

14. Parry SD, Barton JR, Welfare MR. Factors associated with the development of post-infectious functional gastrointestinal diseases: does smoking play a role? Eur J Gastroenterol Hepatol. 2005;17: 1071-5.

15. Kim HS, Kim MS, Ji SW, Park H. The development of irritable bowel syndrome after Shigella infection: 3 year follow-up study. Korean J Gastroenterol. 2006;47:300-5.

16. Marshall JK, Thabane M, Garg AX, Clark WF, Salvadori M, Collins SM. Incidence and epidemiology of irritable bowel syndrome after a large waterborne outbreak of bacterial dysentery. Gastroenterology. 2006;131:445-50, quiz 660.

17. Borgaonkar MR, Ford DC, Marshall JK, Churchill E, Collins SM. The incidence of irritable bowel syndrome among community subjects with previous acute enteric infection. Dig Dis Sci. 2006;51: 1026-32.

18. Stermer E, Lubezky A, Potasman I, Paster E, Lavy A. Is traveler's diarrhea a significant risk factor for the development of irritable bowel syndrome? A prospective study. Clin Infect Dis. 2006;43: 898-901.

19. Marshall JK, Thabane M, Borgaonkar MR, James C. Postinfectious irritable bowel syndrome after a food-borne outbreak of acute gastroenteritis attributed to a viral pathogen. Clin Gastroenterol Hepatol. 2007;5:457-60.

20. Spence MJ, Moss-Morris R. The cognitive behavioural model of irritable bowel syndrome: a prospective investigation of patients with gastroenteritis. Gut. 2007;56:1066-71.

21. Hanevik K, Dizdar V, Langeland N, Hausken T. Development of functional gastrointestinal disorders after Giardia lamblia infection. BMC Gastroenterol. 2009;9:27.

22. Zanini B, Ricci $\mathrm{C}$, Bandera $\mathrm{F}$, et al. Incidence of post-infectious irritable bowel syndrome and functional intestinal disorders following a water-borne viral gastroenteritis outbreak. Am J Gastroenterol. 2012;107:891-9.

23. Cremon C, Stanghellini V, Pallotti F, et al. Salmonella gastroenteritis during childhood is a risk factor for irritable bowel syndrome in adulthood. Gastroenterology. 2014;147:69-77.

24. Persson R, Wensaas KA, Hanevik K, Eide GE, Langeland N, Rortveit $\mathrm{G}$. The relationship between irritable bowel syndrome, functional dyspepsia, chronic fatigue and overactive bladder syndrome: a controlled study 6 years after acute gastrointestinal infection. BMC Gastroenterol. 2015;15:66.

25. Wadhwa A, Al Nahhas MF, Dierkhising RA, et al. High risk of post-infectious irritable bowel syndrome in patients with Clostridium difficile infection. Aliment Pharmacol Ther. 2016;44: 576-82.

26. Andresen V, Lowe B, Broicher W, et al. Post-infectious irritable bowel syndrome (PI-IBS) after infection with Shiga-like toxin-producing Escherichia coli (STEC) O104:H4: a cohort study with prospective follow-up. United European Gastroenterol J. 2016;4:121-31.

27. Rahman MM, Ghoshal UC, Sultana S, et al. Long-term gastrointestinal consequences are frequent following sporadic acute infectious diarrhea in a tropical country: a prospective cohort study. Am J Gastroenterol. 2018;113:1363-75.

28. Parida PK, Mishra D, Pati GK, et al. A prospective study on incidence, risk factors, and validation of a risk score for post-infection irritable bowel syndrome in coastal eastern India. Indian J 
Gastroenterol. 2019;38. https://doi.org/10.1007/s12664-01900943-w.

29. Ali M, Nelson AR, Lopez AL, Sack DA. Updated global burden of cholera in endemic countries. PLoS Negl Trop Dis. 2015;9: e0003832.

30. Noora CL, Issah K, Kenu E, et al. Large cholera outbreak in Brong Ahafo region, Ghana. BMC Res Notes. 2017;10:389.

31. Sauvageot D, Njanpop-Lafourcade BM, Akilimali L, et al. Cholera incidence and mortality in sub-Saharan African sites during multicountry surveillance. PLoS Negl Trop Dis. 2016;10:e0004679.

32. Kaper JB, Morris JG Jr, Levine MM. Cholera. Clin Microbiol Rev. 1995;8:48-86.

33. Bhunia R, Ramakrishnan R, Hutin Y, Gupte MD. Cholera outbreak secondary to contaminated pipe water in an urban area, West Bengal, India, 2006. Indian J Gastroenterol. 2009;28:62-4.

34. Sears CL, Kaper JB. Enteric bacterial toxins: mechanisms of action and linkage to intestinal secretion. Microbiol Rev. 1996;60:167215.

35. Peterson JW, Finkelstein RA, Cantu J, Gessell DL, Chopra AK. Cholera toxin B subunit activates arachidonic acid metabolism. Infect Immun. 1999;67:794-9.

36. Peterson JW, Lu Y, Duncan S, Cantu J, Chopra AK. Interactions of intestinal mediators in the mode of action of cholera toxin. J Med Microbiol. 1994;41:3-9.

37. Peterson JW, Whipp SC. Comparison of the mechanisms of action of cholera toxin and the heat-stable enterotoxins of Escherichia coli. Infect Immun. 1995;63:1452-61.

38. Triadafilopoulos G, Pothoulakis C, Weiss R, Giampaolo C, Lamont JT. Comparative study of Clostridium difficile toxin A and cholera toxin in rabbit ileum. Gastroenterology. 1989;97:1186-92.

39. Guerrant RL, Fang GD, Thielman NM, Fonteles MC. Role of platelet activating factor in the intestinal epithelial secretory and Chinese hamster ovary cell cytoskeletal responses to cholera toxin. Proc Natl Acad Sci U S A. 1994;91:9655-8.

40. Cassuto J, Fahrenkrug J, Jodal M, Tuttle R, Lundgren O. Release of vasoactive intestinal polypeptide from the cat small intestine exposed to cholera toxin. Gut. 1981;22:958-63.

41. Cassuto J, Jodal M, Tuttle R, Lundgren O. On the role of intramural nerves in the pathogenesis of cholera toxin-induced intestinal secretion. Scand J Gastroenterol. 1981;16:377-84.

42. Cassuto J, Jodal M, Lundgren O. The effect of nicotinic and muscarinic receptor blockade on cholera toxin induced intestinal secretion in rats and cats. Acta Physiol Scand. 1982;114:573-7.

43. Sjoqvist A, Cassuto J, Jodal M, Lundgren O. Actions of serotonin antagonists on cholera-toxin-induced intestinal fluid secretion. Acta Physiol Scand. 1992;145:229-37.

44. Nilsson O, Cassuto J, Larsson PA, et al. 5-Hydroxytryptamine and cholera secretion: a histochemical and physiological study in cats. Gut. 1983;24:542-8.

45. Bromander A, Holmgren J, Lycke N. Cholera toxin stimulates IL-1 production and enhances antigen presentation by macrophages in vitro. J Immunol. 1991;146:2908-14.

46. Lycke N, Strober W. Cholera toxin promotes B cell isotype differentiation. J Immunol. 1989;142:3781-7.

47. Munoz E, Zubiaga AM, Merrow M, Sauter NP, Huber BT. Cholera toxin discriminates between $\mathrm{T}$ helper 1 and 2 cells in T cell receptormediated activation: role of cAMP in T cell proliferation. J Exp Med. 1990;172:95-103

48. Fasano A, Fiorentini C, Donelli G, et al. Zonula occludens toxin modulates tight junctions through protein kinase $\mathrm{C}$-dependent actin reorganization, in vitro. J Clin Invest. 1995;96:710-20.

49. Mathan MM, Chandy G, Mathan VI. Ultrastructural changes in the upper small intestinal mucosa in patients with cholera. Gastroenterology. 1995;109:422-30.

50. Silva TM, Schleupner MA, Tacket CO, et al. New evidence for an inflammatory component in diarrhea caused by selected new, live attenuated cholera vaccines and by El Tor and Q139 Vibrio cholerae. Infect Immun. 1996;64:2362-4.

51. Ghoshal UC, Ranjan P. Post-infectious irritable bowel syndrome: the past, the present and the future. J Gastroenterol Hepatol. 2011;26 Suppl 3:94-101.

52. Cocciolillo S, Collins SM. The long-term functional consequences of acute infectious diarrhea. Curr Opin Gastroenterol. 2016;32:1-6.

53. Ghoshal UC, Shukla R, Ghoshal U, Gwee KA, Ng SC, Quigley EM. The gut microbiota and irritable bowel syndrome: friend or foe? Int J Inflam. 2012;2012:151085.

54. Hajela N, Ramakrishna BS, Nair GB, Abraham P, Gopalan S, Ganguly NK. Gut microbiome, gut function, and probiotics: implications for health. Indian J Gastroenterol. 2015;34:93-107.

55. DeGruttola AK, Low D, Mizoguchi A, Mizoguchi E. Current understanding of dysbiosis in disease in human and animal models. Inflamm Bowel Dis. 2016;22:1137-50.

56. Haag LM, Fischer A, Otto B, et al. Intestinal microbiota shifts towards elevated commensal Escherichia coli loads abrogate colonization resistance against Campylobacter jejuni in mice. PLoS One. 2012;7:e35988.

57. Castano-Rodriguez N, Underwood AP, Merif J, et al. Gut microbiome analysis identifies potential etiological factors in acute gastroenteritis. Infect Immun. 2018;86:e00060-18.

58. Dicksved J, Ellstrom P, Engstrand L, Rautelin H. Susceptibility to Campylobacter infection is associated with the species composition of the human fecal microbiota. MBio. 2014;5:e01212-4.

59. Bennet SM, Ohman L, Simren M. Gut microbiota as potential orchestrators of irritable bowel syndrome. Gut Liver. 2015;9:318-31.

60. Collins SM. A role for the gut microbiota in IBS. Nat Rev Gastroenterol Hepatol. 2014;11:497-505.

61. Youmans BP, Ajami NJ, Jiang ZD, et al. Characterization of the human gut microbiome during travelers' diarrhea. Gut Microbes. 2015;6:110-9.

62. Jalanka J, Salonen A, Fuentes S, de Vos WM. Microbial signatures in post-infectious irritable bowel syndrome-toward patient stratification for improved diagnostics and treatment. Gut Microbes. 2015;6:364-9.

63. Jalanka-Tuovinen J, Salojarvi J, Salonen A, et al. Faecal microbiota composition and host-microbe cross-talk following gastroenteritis and in postinfectious irritable bowel syndrome. Gut. 2014;63: 1737-45.

64. Midani FS, Weil AA, Chowdhury F, et al. Human gut microbiota predicts susceptibility to Vibrio cholerae infection. J Infect Dis. 2018;218:645-53.

65. Hsiao A, Ahmed AM, Subramanian S, et al. Members of the human gut microbiota involved in recovery from Vibrio cholerae infection. Nature. 2014;515:423-6.

66. Walker CL, Black RE. Diarrhoea morbidity and mortality in older children, adolescents, and adults. Epidemiol Infect. 2010;138: 1215-26.

67. Rahman MM, Mahadeva S, Ghoshal UC. Epidemiological and clinical perspectives on irritable bowel syndrome in India, Bangladesh and Malaysia: a review. World J Gastroenterol. 2017;23:6788-801.

68. Lovell RM, Ford AC. Global prevalence of and risk factors for irritable bowel syndrome: a meta-analysis. Clin Gastroenterol Hepatol. 2012;10:712-21 e4.

69. Gwee KA, Lu CL, Ghoshal UC. Epidemiology of irritable bowel syndrome in Asia: something old, something new, something borrowed. J Gastroenterol Hepatol. 2009;24:1601-7.

70. Klem F, Wadhwa A, Prokop LJ, et al. Prevalence, risk factors, and outcomes of irritable bowel syndrome after infectious enteritis: a systematic review and meta-analysis. Gastroenterology. 2017;152: $1042-54$ e1. 
71. Thabane M, Simunovic M, Akhtar-Danesh N, Marshall JK. Development and validation of a risk score for post-infectious irritable bowel syndrome. Am J Gastroenterol. 2009;104:2267-74.

72. Mathan VI, Baker SJ. Epidemic tropical sprue and other epidemics of diarrhea in south Indian villages. Am J Clin Nutr. 1968;21:1077-87.

73. Ghoshal UC, Gwee KA. Post-infectious IBS, tropical sprue and small intestinal bacterial overgrowth: the missing link. Nat Rev Gastroenterol Hepatol. 2017;14:435-41.

74. Ghoshal UC, Srivastava D, Verma A, Ghoshal U. Tropical sprue in 2014: the new face of an old disease. Curr Gastroenterol Rep. 2014;16:391.

75. McCarroll MG, Riddle MS, Gutierrez RL, Porter CK. Infectious gastroenteritis as a risk factor for tropical sprue and malabsorption: a case-control study. Dig Dis Sci. 2015;60:3379-85.
76. Ghoshal UC, Mehrotra M, Kumar S, et al. Spectrum of malabsorption syndrome among adults \& factors differentiating celiac disease \& tropical malabsorption. Indian J Med Res. 2012;136:451-9.

77. Yadav P, Das P, Mirdha BR, et al. Current spectrum of malabsorption syndrome in adults in India. Indian J Gastroenterol. 2011;30: 22-8.

78. Dutta AK, Balekuduru A, Chacko A. Spectrum of malabsorption in India-tropical sprue is still the leader. J Assoc Physicians India. 2011;59:420-2.

Publisher's note Springer Nature remains neutral with regard to jurisdictional claims in published maps and institutional affiliations. 